\title{
The Impact of Using Twitter as a Pedagogical Tool on Improving Writing Skills of English Language Education Students
}

\author{
Risnawati $^{1}$, Abdurrachman Faridi ${ }^{2}$, Sri Wuli Fitriati ${ }^{3}$ \\ ${ }^{1}$ English Language Education Study Program. \\ ${ }^{2,3}$ Graduate Program, Universitas Negeri Semarang, Jawa Tengah, Indonesia. \\ Corresponding Author: Risnawati
}

DOI: https://doi.org/10.52403/ijrr.20220118

\begin{abstract}
This study was a qualitative research method focused on a case study approach. This study aimed to find out the impact of pedagogical Twitter on improving the writing skills of English Language Education students at Universitas Pendidikan Muhammadiyah (UNIMUDA) Sorong. The sample of this study was 27 students of the English Language Education Study Program in the academic year $2020 / 2021$. The sampling technique of this study used a purposive sampling technique. Invalidating the data, I used methodological and investigator triangulation. The instrument of this study had validated by expert judgment invalidating the data. The data of this study had collected through students writing text, tweets from Twitter, and interviews. After collecting the data, I used Brown's rubric score to analyze students' writing text, and tweets from their Twitter accounts as a pre-test and post-test. The interview item became the last instrumental in exploring the impact of Twitter on improving students writing skills. The analysis found that Twitter became an effective tool in enhancing students' writing skills. The result showed from five categories of Brown's assessing writing skills: students writing content of $83.33 \%$, the organization was $81.48 \%$, grammar structures of $85.19 \%$, vocabulary had $82.41 \%$, and mechanism had $100.00 \%$. The result concluded that Twitter was more influential in improving students writing skills. The average of each category was an outstanding category. In short, Twitter became an effective pedagogical tool in helping students to improve their writing skills.
\end{abstract}

In addition, Twitter has functioned as social media, but it has integrated into the teaching and learning process.

Keywords: Twitter, Pedagogical Tool, Writing Skills

\section{INTRODUCTION}

Twitter is one of the social media used by people to facilitate their communication activities among other popular social platforms such as Facebook, Instagram, WhatsApp, Blog, Web, LinkedIn, etc. Twitter might become a particular interest in higher education students in the digital era. It was because of the quantity of information and format. Twitter has organized a new style bulletin, which conveyed up from 140 to 280 characters last September 2017 that the user can monitor. It could help more users of Twitter to tweet in the English language. The main reason why Twitter updated their characters to 280 was that the language used in tweeting through the English language needed more language than Japanese, Chinese, and Korean languages. So that, Twitter made their users more enjoyable in tweeting.

According to Jacquemin et al. (2014), social media platforms such as Twitter, Facebook, and Instagram became the forum for post-in-class questions for a large-scale display and discussion in the undergraduate classroom. As social 
networking, Twitter integrated into the learning process in helping English Language Learner skills. Through Twitter, it hoped that the medium would overcome students' problems in the mastery of their English language skills. The language skill that had to integrate by using Twitter was writing skills.

Writing was one of the English language subjects that had complex skills. It was also one of the compulsory subjects for senior high school and university students. The writing aimed to make students reach a functional level to communicate both in written and spoken form. Writing means creating or producing spoken messages into written form. It involved an active process in organizing and developing ideas on the paper, so the reader knew the authors' intent (Salikin \& Tahir, 2017).

Those statements explained if writing was a difficult skill for native and non-native speakers, such as students. In this case, they should balance multiple issues such as content, organization, grammar structure, vocabulary, and mechanics. Writing skills were complex because English as a foreign language would need English writing skills ranging from a simple paragraph and summary skills in writing essays and professional articles. As students enter the workforce, they will convey ideas and information (Abd et al., 2015).

Linked with those statements above, Twitter could help the English Language Education Study Program students in the academic year 2020/2021 at Universitas Pendidikan Muhammadiyah (UNIMUDA) Sorong to improve their writing skills and expand their ability to write some topics in the English language. Twitter became appropriate as a social media platform for young students in writing, editing, revising issues in the English language in the classroom activity. It indicated that comparing the use of Twitter with regular blogging and micro-blogging makes communication faster by using Twitter as a tool in learning activities.
Lomicka \& Lord (2012) stated Twitter as a tool in language and learning has a role in language production. The use of Twitter in classroom activity has shown potential in myriad ways to support authentic learning tools in the teaching and learning process. Besides that, as a tool in fostering students' language production, micro-blogging had a role in promoting a sense of community beyond the classroom walls to learn, share, reflect, and communicate. So, that was why Twitter has more potential in helping students in higher education extend their learning outside of the classroom to encourage them to use the target language more often.

As the higher students' social media used, Twitter became more prevalent. It was time to question more influence using Twitter as a model in public communication with university students. The effectiveness of communication between lecturer and students became a significant thing in this study. Veletsianos et al. (2013) indicated that Twitter is used in higher education to help both students and lecturers in teaching and learning. The use of Twitter in university aimed to determine undergraduate students were choosing Twitter as their social networking when they tried to share a moment and post any information on Twitter accounts. West et al. (2015)) suggested that Twitter positively impacts students' performance and perception of their learning experience from their overall result of using Twitter. Using Twitter helped the students extend their learning outside the classroom and encouraged them to use the target language more often.

Many researchers investigated the impact of Twitter on improving students' writing skills, namely Carpenter and Krutka (2014), Cohen and Duchan (2012), Lin et al. (2013), Olive et al. (2015), Yuan (2012), Waters \& Jamal (2011), and Welch \& Bonnan-White (2012). These previous studies had approved that Twitter could help students improve their writing skills without worrying about their mistakes in the writing 
classroom. They could tweet anytime about what they wanted to post on Twitter. It gave the advantages for the students to explore more about Twitter.

The advantages of Twitter in the education context explained by Bista (2015) there were: 1) wasting time as students write irrelevant tweets, 2) constraints towards freedom of expression and weakening of students grammatical skills because of tweets word limit, and 3) privacy-related concerns due to open accessible nature of Twitter.

The use of Twitter in writing skills transformed Twitter into a sophisticated and flexible writing tool that improved the learners' writing skills, which led to academic success and their attitude toward writing. Last but not least, the student could make Twitter a tool to help them in writing activities without the need for a pen and paper. Writing was a productive skill that required students to organize an idea and produce a new concept. The most important thing about this skill was that it could not separate from other language skills. Kim (2010) revealed that Twitter affects learners of any language. It created a sense of community among the users as well. Kim also stated that Twitter enables students of all ages to practice writing well and provides a reasonable opportunity to use English spontaneously for an authentic purpose. As the most popular social media, Twitter became an essential tool in the writing classroom. Twitter also helped the students to write or tweet and share information in real-time through private or public messages.

Alqunayeer (2016) stated that teaching English as a foreign language has changed in the last few decades. Currently, teaching English language teaching methodologies focus on giving the learners' opportunity to communicate in the classroom. He claimed that nowadays, teaching the English language needed media to support lecturers for motivating their students' awareness by using media such as Twitter. Using social networking (Twitter) allowed increasing student learning by providing more space for finding teaching material. Students could have more room to find documentation information through images, links, and written material.

Consequently, it could become a valuable resource to support their scholarly communication and collaborations with faculty (Roblyer et al., 2010). Twitter was an effective tool for improving the students' writing skills, especially in brainstorming ideas before the actual writing activity. The use of Twitter in the teaching and learning process can support the process of writing, and the students develop their writing skills in various genres.

Moreover, a study conducted by Ekinci (2018)stated that Twitter enables students of all ages to practice good writing and provides a reasonable opportunity for them to use English spontaneously for authentic purposes. In her study explained that the use of Twitter could lead to a new way to cope with writing deficiencies and turn this agonizing process into a more demanding and interactive way thanks to the dynamic, joyful, and nature of such social microblogging site, in this case, Twitter.

Writing on Twitter can be considered intensive writing since it was just a phrase or a sentence. Sometimes, the writing does not always have explicit meaning, even though it can have multiple meanings that people cannot predict. Leitch \& J. Warren (2011) stated that using social media enhances students writing skills in teaching and learning. The lecturer's duty became to make their students feel comfortable in the writing classroom.

Teaching writing in university became a considerable part of the subject matter of the lecturer that should pay attention to while in the teaching and learning process. The study conducted by Fitriati and Fitriati and Solihah (2019) stated that writing was one of the necessary skills for university students, notably for learners of English Second Language (ESL) or English for a Foreign Language (EFL). English learners had taught to produce good 
academic writing through language use in the written activity process. In teaching language learning, mainly writing, the lecturer should prepare a unique method to deliver their material to students to understand and use well (Faridi, 2013). The teacher or lecturer had expected to reach learning objectives accurately in teaching the English language.

Understanding the complexity was the key to effective teaching writing (Cheung, 2016). Writing skills became the subject were helping the learners to develop and employ several skills such as analyzing, arguing, critic, comparing, and contrasting arguments. Writing skills are crucial skills that learners need to build for their academic success. In teaching writing, the lecturer should be aware of how to teach their students in various ways to make writing activities more enjoyable.

Based on the statements above, it concluded that Twitter became an effective tool in helping the students to improve their writing skills. Besides that, it became the reason for the researcher to conduct a study in the English Language Education Study Program of Universitas Pendidikan Muhammadiyah (UNIMUDA) Sorong for improving their writing skills.

\section{MATERIALS \& METHODS}

This study used a descriptive qualitative method with a case study analysis. This study was conducted in the English Language Education Study Program at Universitas Pendidikan Muhammadiyah (UNIMUDA) Sorong. The data had collected through students' writing text, tweets from students' Twitter accounts, and interview guides.

The data source used in this study was a purposive sampling technique based on particular characteristics. The data source was a writing course of the English Language Education Study Program in the academic year 2020/2021 at Universitas Pendidikan Muhammadiyah (UNIMUDA) Sorong.
The technique validity data in this study used methodological and investigator triangulation. Methodological triangulation consists of using more than one method to gather data. Investigator triangulation consists of using multiple researchers in an empirical study, and methodological triangulation consists of using more than one theoretical framework to interpret the data. The data was analyzed using Brown's rubric score of writing assessment to gain the student writing skills (Brown, 2007).

\section{RESULT}

Based on the research conducted on English Language Study Program at Universitas Pendidikan (UNIMUDA) Sorong, regarding the impact of Twitter as a pedagogical tool on improving writing skills in five aspects of writing would describe as follows:

\section{The Impact of Pedagogical Twitter on Improving Students' Content Writing}

The first objective of this study was to explain the impact of Twitter on improving students' content of writing text by the students of the English Study Program in writing subject at the Universitas Muhammadiyah Pendidikan (UNIMUDA) Sorong through using Twitter. In analyzing the students' knowledge on improving students' content in writing text, the students had given pre-text and post-test. Based on the Brown analysis on writing skills, found out the findings of pre-test and post-test that presented in table 1 below.

Table 1 Final Result of Content Category
\begin{tabular}{|l|l|l|l|l|}
\hline Test Forms & $\boldsymbol{\Sigma}$ & Total Score & Percentage & Category \\
\hline Pre-Test & 27 & 71 & 65.74 & Fair \\
\hline Post-Test & 27 & 90 & $83.33 \%$ & Good \\
\hline
\end{tabular}

Table 1 showed that the score of pretests from 27 students was 71 , with $65.74 \%$ in the fair class. In post-test scores from 27 students, the total score was 90 with the rate of $83.33 \%$ that was in a good variety. The findings showed a different score after using Twitter in the writing activity. The significant number increased high than students writing text. It explained if Twitter 
had more impact on helping students learn the content of writing activities. So, it concluded that the effect of Twitter on improving the content category in writing tests was good.

\section{The Impact of Twitter as a Pedagogical Tool on Improving Students' Organization Writing}

The second objective of this study was to explain the organization that the students in their writing activity did. The students who were used to writing and posting a topic on their Twitter account as a tool in learning writing skills should be known how to organize a written in their writing activities. In connection with the students' organization, written text in writing skills. The pre-test and post-test findings are presented in table 2 below.

Table 2 Final Result of Organization Category

\begin{tabular}{|l|l|l|l|l|}
\hline Test Forms & $\Sigma$ & Total Score & Percentage & Category \\
\hline Pre-Test & 27 & 56 & 51.85 & Poor \\
\hline Post-Test & 27 & 88 & $81.48 \%$ & Good \\
\hline
\end{tabular}

Table 2 showed that the score of pretests from 27 students was 56, with 51.85\% in the poor category. The post-test score from 27 students was 88, with a rate of $81.84 \%$ in a good variety. The result showed that the organization category of writing skills had increased in the post-test from the pre-test score. Based on the outcome, Twitter significantly impacted the organization category of writing skills. It described that the students improve their understanding in a tweet by using Twitter as a pedagogical tool in the learning organization category of writing skills.

\section{The Impact of Pedagogical Twitter on Improving Students' Grammar Structure Writing}

The third objective was to analyze the impact of pedagogical Twitter on improving students' grammar structures in writing text. To answer research question number 3 and the analysis of the effects of Twitter in the use of grammar structure by the students who both were using students' written text and Twitter accounts. The result findings of the pre-test and the post-test are presented in table 4.3 below.

Table 3 Final Result of Grammar Structures

\begin{tabular}{|l|l|l|l|l|}
\hline Test Form & $\boldsymbol{\Sigma}$ & Total Score & Percentage & Category \\
\hline Pre-Test & 27 & 59 & 54.63 & Poor \\
\hline Post-Test & 27 & 92 & $85.19 \%$ & Good \\
\hline
\end{tabular}

Table 3 above showed that the total score of students in grammar structure in the pre-test was 59 , with $54.63 \%$ in the poor category. Then, the student's total score in grammar structure was 92, with a ratio of $85.19 \%$ in a good variety. Through the average rate of pre-test and post-test of students' understanding of grammar structure, there was a significant impact of pedagogical Twitter in the use of grammar structure in students' writing activities. So, it concluded that the findings of the effect of pedagogical Twitter in the use of grammar structure in students' writing activities had a significant result for the university students in enhancing their writing skills.

\section{The Impact of Twitter on Improving Students' Vocabulary Writing}

The fourth objective was to analyze the impact of Twitter on improving students' vocabulary writing. The students who posted a topic on Twitter should look carefully at the vocabulary available in their posts. While posting something on Twitter, students who post an issue must be careful to put vocabulary related to the topic. As Brown (2007) stated, vocabulary was one aspect of writing that should fulfill in a writing course. The pre-test and post-test results of vocabulary showed in table 4 below.

Table 4.5 Final Result of Vocabulary Category
\begin{tabular}{|l|l|l|l|l|}
\hline Test Forms & $\boldsymbol{\Sigma}$ & Total Score & Percentage & Category \\
\hline Pre-Test & 27 & 60 & 55.56 & Fair \\
\hline Post-Test & 27 & 89 & $82.41 \%$ & Good \\
\hline
\end{tabular}

Table 4 showed that the total score pre-test of students' vocabulary from 27 students was 60 with a percentage of $55.56 \%$ was in the fair class. Then, the total score post-test of students' vocabulary from 27 students was 89 , with the rate of $82.41 \%$ was in a good variety. Both findings explained if students' vocabulary using 
Twitter and not using Twitter was significantly impacted by seeing from the post-test score. The post-test results of students' vocabulary indicated if they considerably increased their writing skills. It explained that the findings showed the percentage of post-test has achieved a significant effect than the percentage of the pre-test. So, the average students' vocabulary had a tremendous impact while using Twitter as a pedagogical tool in learning writing skills. So, it showed up if Twitter became an effective way to increase students' writing skills vocabulary.

\section{The Impact of Twitter as the Pedagogical Tool on Improving Students Mechanism Writing}

The fifth objective was to analyze the impact of Twitter as a pedagogical tool on improving students' mechanism writing. Concerning Brown's writing assessment, this study would explore how the students' arranged an excellent mechanism, including spelling, punctuation, and capitalization. At the same time, they were written in both using writing on paper and Twitter accounts. The findings pre-test and post-test of students mechanism presented in table 5 below:

Table 4.6 Final Result of Mechanism Category

\begin{tabular}{|l|l|l|l|l|}
\hline Test Forms & S & Total Score & Percentage & Category \\
\hline Pre-Test & 27 & 63 & $58.33 \%$ & Fair \\
\hline Post-Test & 27 & 108 & $100.00 \%$ & Very Good \\
\hline
\end{tabular}

Based on table 4.5 above, the score pre-test of students' mechanism was 63 from 27 students with $58.33 \%$ in the fair class. Then, the score post-test of students' mechanism was 108 from 27 students with $100.00 \%$ in the excellent category. Seen through the percentage of the mechanism showed better results in using Twitter than without using Twitter. The ratio presented in the students' mechanism while using Twitter as their learning tool gained significant results. The post-test result showed if Twitter became the practical way in helping the student to increase their mechanism. So, based on the post-test result, it concluded that Twitter had a significant impact as a pedagogical tool in the mechanism category of students writing skills.

\section{The Impact of Twitter on Improving Students' Writing Skills}

The sixth objective of this study was the impact of Twitter on improving student writing skills. This section will show the pre-test and the post-test students writing skills before the interview item revealed in this study. The final writing skills result is presented in Figures 1 and 2 below.

\section{Final Result of All Category}

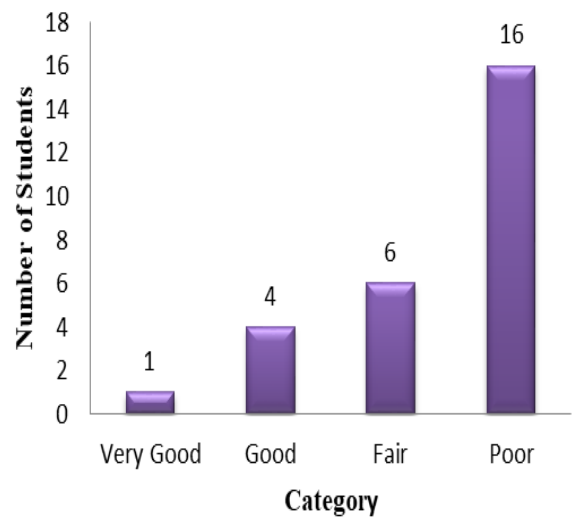

Figure 1 Final Pre-Test Result of All Category in Writing Skills

Figure 1 above presented the findings pre-test of students writing skills. The pre-test showed the percentage of the excellent category has $1 \%$, a good variety has $4 \%$, a fair class has $6 \%$, and a poor class has $16 \%$. Those findings explained that the students who used to write without using Twitter only $1 \%$ excellent category, and $16 \%$ in the poor class. So, it concluded that students who used writing text did not significantly impact when they were not using Twitter.

Related to the pre-test findings, I would be showing the post-test result of students writing skills that used Twitter as their media in the learning process. The findings of post-test of students writing skills that used Twitter are presented in the chart below: 


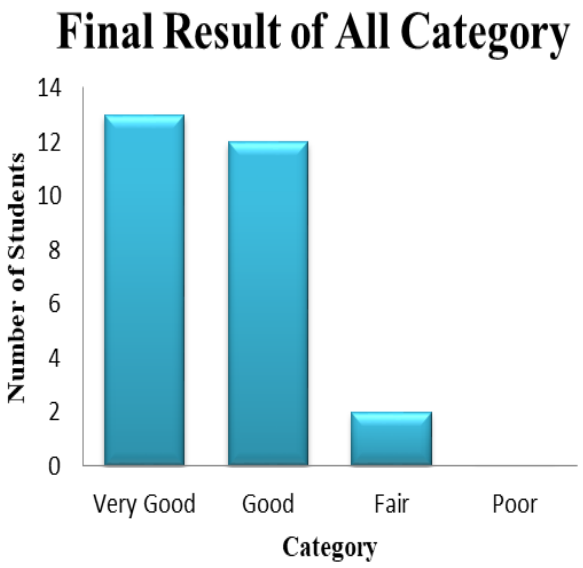

Figure 2 Final Post-Test Result of All Category in Writing Skills

Figure 2 above shows the post-test findings of students writing skills using Twitter. The result showed that the percentage of the excellent category has $14 \%$, a good variety has $12 \%$, a fair class has $2 \%$, and a poor variety has $0 \%$. Those findings explained that all aspects of writing skills gained a significant result when using Twitter as the learning tool in their writing classroom activities. So, it concluded that Twitter had a positive impact on increasing students writing skills.

In supporting the pre-test and posttest findings, I gave the following interview items of the impact of Twitter on improving students' writing skills in the first semester of the English Language Study Program at Universitas Pendidikan Muhammadiyah (UNIMUDA) Sorong, Papua Barat. Interview confirmed by the interviewees of ST_12 related to the question of how is writing learning activities using Twitter as a learning media? Stated that "Twitter is a good application in writing learning activities. It could also help us integrate Twitter as a learning medium into the writing classroom" (interviewed on February 2, 2021). Continued with the other interview about Twitter could facilitate writing learning activities supported by the interviewees of ST_12 on the same day confirmed that "Twitter is an application used as social media and beneficial for learning and writing activities. So, it helps us to get more knowledge and information in enhancing our writing skills." The same statements stated by the interviewees of ST_13 noted that "Twitter could facilitate us as a student in writing learning activities" (February 2, 2021)

The interviews above showed that learning writing done by using Twitter indicated that Twitter as a learning medium helped the learners increase their writing skills. Continued with the other interview items about Twitter being useful for writing learning activities, supported by the interviewees' statement of ST_12 asserted that "She thought Twitter is useful for helping the students in writing learning activities. When we updated Twitter, status could be seen from Indonesia and outside Indonesia. It stated that Twitter is one of the online media that gaining more users besides other social media such as Instagram, Facebook, etc." (interviewed February 2, 2021). The interviewees of ST_17 also supported it stated that "Twitter is beneficial for helping her in writing activities.”

Based on the interviews done by the students about the impact of Twitter in the learning of writing skills for university students, students showed that students were more enjoyable, accessible, and fun doing their writing activities by using a Twitter medium. In this study, I took only a onetime interview because my researcher had done it during the pandemic of Covid- 19 . So, through some items of interviews, it can be concluded that the writing learning process by using Twitter as a pedagogical tool positively impacted university students in increasing their writing skills. So, Twitter as the learning medium was better to apply Twitter in the writing classroom activities in helping students writing ability for the future learning writing classroom.

\section{DISCUSSION}

The Impact of Pedagogical Twitter on Improving Students' Content Writing

Related to using Twitter as a pedagogical tool for improving students' writing content, Chew and Eysenbach 
(2010)analyzed tweets’ content in pandemic situations. Their statement explained the tweets of content that referred to what happened in the pandemic. It had described based on Brown's who stated that content in the writing skills should be related to the topic and the background of the writing text.

In line with the statement above, Tatone et al. (2017) discovered that Twitter could sustain students' attention in understanding the lecturer's content during writing class. The lecturer should remind the student to keep tweets relevant to the lecturers during writing class. Some students need their lecturer to send reminders, so they do not have to see the distracting content or call out their classmates who were tweeting irrelevant content (Tyma, 2011). A teaching lecturer could handle these reminders while seeing off-topic tweets during the teaching and learning process. Another issue was whether the live tweets with the class hashtag should project onto the classroom wall.

It concluded if Twitter could improve students' content writing skills in the English Language Education Study Program at Universitas Pendidikan Muhammadiyah (UNIMUDA) Sorong Papua Barat.

\section{The Impact of Twitter as a Pedagogical Tool on Improving Students' Organization Writing}

Investigate the use of Twitter blended with the writing activity; it had viewed from the learning writing activity and technology Blankenship and Margarella (2014:147) stated that situated learning theory is used to explain the cognitive and social environment in the classroom. In conceptualizing the writing process, the tenets of writing should include examining the students writing skills that used Twitter as a pedagogical tool. Related to the report, students should recognize the impact of Twitter as a pedagogical tool in the organization of writing text.

Sulisworo et al. (2016:177) explained the development of information and communication technology dominated by tablets, smartphones, and touch screen devices for various interests in learning. Mobile learning became a new alternative for enhancing students' learning organization of writing skills activities. One approach that made mobile and classroom learning used was blended learning, in this case, Twitter. This approach allowed students to know better about the organization category in the writing activity.

\section{The Impact of Pedagogical Twitter on Improving Students' Grammar Structure Writing}

Ellis and Shintani (2014) guided the learners to notice the gap between the ideal and the existing knowledge, recognize what was lacking or wrong in their writing output and their language. Their statement explained the students' understanding of their writing output that impacted their skill in the grammar structure category of the writing text. Twitter focused users on being concise and got the right to the point on their tweets.

Aloraini (2018) stated that the use of Twitter in teaching writing also triggered the students to communicate with their friends and offered the opportunity for interaction which was meaningful and less intimidating incredibly for introverted students. Writing in the online platform through using Twitter also motivated the students to have the responsibility to do the best writing performance they could do and continue learning after writing class. People may not understand what they wrote if their sentences were ungrammatical or not followed by the grammar structures rule and if they misspelled words or used incorrect punctuation. Focusing on the form of the sentence structure was not enough in the writing skills activities. It concluded that Twitter as a pedagogical tool significantly impacted grammar structures in students writing activities. 


\section{The Impact of Twitter on Improving Students' Vocabulary Writing}

Santana et al. (2014) explained that

to help students in the mastery of vocabulary in their writing skills, it should help by using mobile technology. Mobile technology means using Twitter as an alternative way to help students write. Twitter became an easy tool in teaching vocabulary because it had accessed through the phone. It allowed the students to learn new words that became one of the problems which permanently blocked their ideas when in writing activities.

The study of Pérez-Sabater and Montero (2015:133) explained the crucial impact of vocabulary acquisition had based on the issues or topics of the material discussed. The lecturer should be aware of using words in teaching writing material related to using Twitter as a mobile learning tool in the learning process. The lecturer should teach the students the words that learners need to know and the means to help them enhance their vocabulary list in written activities. The lecturer should pay the students for the new words learned in written activities, which might promote their language acquisition. So, it showed up if Twitter became an effective way to increase students' writing skills vocabulary.

\section{The Impact of Twitter as the Pedagogical Tool on Improving Students Mechanism Writing}

Based on the pre-test and the posttest analysis, both findings showed that the scores of students' mechanisms gained a significant result in writing skills. The score of the pre-test was 63 that was in the fair class, and the post-test was 108 in the excellent variety, which means that the percentage from pre-test to post-test had gained significantly in the students' mechanism category.

Altakhaineh and Al-Jallad (2018) also supported this study stated EFL lecturers usually focus on specific writing skills and mechanisms that students need to learn and to be able to produce a good piece of writing in the EFL classroom. Regarding the connection of ideas at the level of the sentences/cohesion, the lecturer should check whether students use grammar correctly when in the writing activities.

Related to the use of Twitter in increasing students writing skills, Sysoyev and Pustovalova (2014:131) explained if Twitter in increasing students writing skills became an appropriate tool in the learning process that considered the methodological potential of using Twitter in helping students on writing activity.

Related to the Twitter function in the learning writing classroom, Diverniero and Hosek (2013, p. 50) asserted that the integration of Twitter in the writing classroom was beneficial for university students to increase their writing skills. As the learning tool, Twitter had a function that allowed the users to access their updates, easy to tweet, help the shy students post their ideas, and increase their participation in writing activities.

The analysis of five aspects of writing skills showed us a good result when students used Twitter in the post-test score than students who wrote without using Twitter in the pre-test score. So, it concluded that Twitter positively impacted helping and increasing students' writing skills for the English Language Education Study Program at Universitas Pendidikan Muhammadiyah (UNIMUDA) Sorong, Papua Barat, in the first semester in the academic year 2020/2021.

\section{The Impact of Twitter on Improving Students' Writing Skills}

Luo and Xie (2019, p. 98) revealed that students who use technology in their communication medium perceived Twitter as a more beneficial tool integrated into the writing classroom. In their study, they compared two classes regarding the use of Twitter. The two classes showed that the student in communication perceived Twitter in their learning activities than the students on the education side. 
Regarding the use of Twitter in writing learning activities as a technology tool in learning, Ghahri et al. (2015, p. 1949) stated that technology and English language education were highly related to each other. They described if technology in English language education helped the English Foreign Language learners improve their language skills, especially in the writing classroom activities.

Related to the use of Twitter in the writing activities, Siddique and Nair (2015) stated that students could quickly enter text on Twitter as a mobile learning tool compared to writing with a pen and edit and revise students writing text.

Twitter could facilitate students' writing ability by providing input to engage an audience online for their writing output. The students use Twitter to interact with each other through the online community to increase their writing ability. Twitter has become a more effective student interaction and relationship than if communication were one-way.

Based on the expert statements about the use of Twitter on improving students' writing skills. It concluded that Twitter as an educational tool positively impacted students' writing skills in the first semester of the English Language Education Study Program at Universitas Pendidikan Muhammadiyah (UNIMUDA) Sorong in 2020/2021.

\section{CONCLUSION}

This study analyzed the impact of using Twitter as a pedagogical tool on content, organization, grammatical structure, vocabulary, and mechanism and the effect of educational Twitter on enhancing writing skills for university students. Based on the analysis of the data in the previous chapter, the conclusion reached as follows:

First, Twitter as the pedagogical tool for improving students' content of writing text positively impacted the student's understanding of the writing content. Second, the students who used Twitter as a pedagogical tool for improving students' writing skills showed a good result from the organization category analysis. Third, the post-test analysis of the grammar structure used in learning writing text had a good effect when using Twitter as a learning tool in the writing activities classroom. Fourth, Twitter accounts in the vocabulary category showed a good result. The analysis of the use of vocabulary was from the post-test result. It showed that using language while using Twitter had significantly increased students' writing skills. Fifth, the use of Twitter on improving students' mechanisms of writing skills had a positive impact. The result came from the post-test analysis of the use of mechanism category on students writing skills. Last, the interview analysis showed that Twitter as a mobile learning tool had a positive impact. This result came from the post-test analysis of students' perspectives on using Twitter in learning activities.

The study's outcome and significance suggested it would be valuable for English teachers, students, and other researchers interested in using Twitter as an educational tool in the writing class. It was interesting to research using Twitter as a pedagogical tool by following five aspects of writing skills for future research.

Acknowledgement: None

\section{Conflict of Interest: None}

\section{Source of Funding: None}

\section{REFERENCES}

1. Abd, M., Ali, E., \& Ahmed, S. (2015). The effect of Twitter on developing writing skills in English as a foreign language. Arab World English Journal (AWEJ) Special Issue on CALL, 2, 134149. www.awej.org/Accessed:2020-11-22

2. Aloraini, N. (2018). Investigating Instagram as an EFL learning tool. Arab World English Journal, 4(4), 174-184. https://doi.org/10.24093/awej/call4.13

3. Alqunayeer, H. S. (2016). The impact of teaching through Twitter on students' 
vocabulary learning: A case study of Qassim University. World Journal of English Language, 6(2), 1-35. https://doi.org/10.5430/wjel.v6n2p35

4. Altakhaineh, A. R. M., \& Al-Jallad, M. Z. (2018). The use of Twitter and Facebook in teaching mechanics of writing to Arabic-speaking EFL learners. International Journal of Emerging Technologies in Learning, 13(9), 4-14. https://doi.org/10.3991/ijet.v13i09.8457

5. Bista, K. (2015). Is Twitter an effective pedagogical tool in higher education? Perspectives of education graduate students. Journal of the Scholarship of Teaching and Learning, 15(2), 83-102. https://doi.org/10.14434/josotl.v15i2.1282 5

6. Blankenship, M. U., \& Margarella, E. E. (2014). Technology and secondary writing: A review of the literature. Contemporary Educational Technology, 5(2), 146-160. https://doi.org/10.30935/cedtech/6121

7. Brown, H. D. (2007). Language Assessment: Principles and Classroom Practices. New York: Pearson Education.

8. Carpenter, J. P., \& Krutka, D. G. (2014). How and why educators use Twitter: A survey of the field. In Journal of Research on Technology in Education (Vol. 46, Issue 4, pp. 414-434). Routledge. https://doi.org/10.1080/15391523.2014.92 5701

9. Cheung, Y. L. (2016). Teaching Writing. In Teaching Writing (pp. 179-194). Springer. https://doi.org/10.1007/978-3319-38834-2_13

10. Chew, C., \& Eysenbach, G. (2010). Pandemics in the age of Twitter: Content analysis of tweets during the $2009 \mathrm{H} 1 \mathrm{~N} 1$ outbreak. PLoS ONE, 5(11), e14118. https://doi.org/10.1371/journal.pone.0014 118

11. Cohen, A., \& Duchan, G. (2012). The usage characteristics of Twitter in the learning process. Interdisciplinary Journal of E-Skills and Lifelong Learning, 8, 149163. https://doi.org/10.28945/1733

12. Diverniero, R., \& Hosek, A. M. (2013). Twitter as a classroom tool: Exploring the use, benefits, and downfalls from the perspectives of instructors and students. Journal of Social Media in Society, 2(2), 48-75.

https://thejsms.org/index.php/JSMS/article /view/21/Accessed-2021-09-17

13. EKİNCI, E. (2018). Effects of Twitter on EFL students' academic success in writing. International Journal of Languages' Education, 1(Volume 6 Issue 3), 89-102. https://doi.org/10.18298/ijlet.3136

14. Ellis, R., \& Shintani, N. (2014). Exploring Language Pedagogy through Second Language Acquisition Research. New York, NY: Routledge. https://www.taylorfrancis.com/books/mon o/10.4324/9780203796580/exploringlanguage-pedagogy-second-languageacquisition-research-rod-ellis-natsukoshintani/Accessed:2021-08-31

15. Faridi, A. (2013). Methods used in teaching English at junior high schools in central Java. ELTL Indonesia Conference Proceedings 2012., 3, 226-238. https://awej.org/index.php/2013-04-17-1220-35/36-eltl-indonisia-2012/268-

abdurrachman-faridi/2020-12-10

16. Fitriati, S. W., \& Solihah, Y. A. (2019). Non-native writers and the use of appraisal resources in research article introductions. Indonesian Journal of Applied Linguistics, 8(3), 638-645. https://doi.org/10.17509/ijal.v8i3.15265

17. Ghahri, F., Hashamdar, M., \& Mohamadi, Z. (2015). Technology: A better teacher in writing skills. Theory and Practice in Language Studies, 5(7), 1495. https://doi.org/10.17507/tpls.0507.24

18. Jacquemin, S., Smelser, L., \& Bernot, M. (2014). Twitter in the higher education classroom: A student and faculty assessment of use and perception. Journal of College Science Teaching, 43(9), 2227.

https://doi.org/10.2505/4/jcst14_043_06_2 2

19. Kim, H. (2010). Three teachers' initial efforts to use Twitter for teaching English in public schools. Multimedia-Assisted Language Learning, 13(2), 129-154. https://doi.org/10.15702/mall.2010.13.2.1 29 
Risnawati et.al. The impact of using twitter as a pedagogical tool on improving writing skills of English language education students.

20. Leitch, S., \& J. Warren, M. (2011). Social networking and teaching: An Australian case study. Proceedings of the 2011 InSITE Conference, 315-326. https://doi.org/10.28945/1462

21. Lin, M. F. G., Hoffman, E. S., \& Borengasser, C. (2013). Is social media too social for class? A case study of Twitter use. TechTrends, 57(2), 39-45. https://doi.org/10.1007/s11528-013-06442

22. Lomicka, L., \& Lord, G. (2012). A tale of tweets: Analyzing microblogging among language learners. System, 40(1), 48-63. https://doi.org/10.1016/j.system.2011.11.0 01

23. Luo, T., \& Xie, Q. (2019). Using Twitter as a pedagogical tool in two classrooms: A comparative case study between an education and a communication class. Journal of Computing in Higher Education, 31(1), 81-104. https://doi.org/10.1007/s12528-018-91922

24. Olive, A., Samper, X., Cuadros, J., Martori, F., \& Serrano, V. (2015). Answering questions concisely: analysis of a Twitter activity in a management course. Procedia - Social and Behavioral Sciences, 182, 179-186. https://doi.org/10.1016/j.sbspro.2015.04.7 54

25. Pérez-Sabater, C., \& Montero-Fleta, B. (2015). ESP vocabulary and social networking: The case of Twitter. Ibérica, 29(29), 129-154. https://www.academia.edu/12071865/ESP _vocabulary_and_social_networking_The _case_of_Twitter/Accessed:2021-09-10

26. Roblyer, M. D., McDaniel, M., Webb, M., Herman, J., \& Witty, J. V. (2010). Findings on Facebook in higher education: A comparison of college faculty and student uses and perceptions of social networking sites. Internet and Higher Education, 13(3), 134-140. https://doi.org/10.1016/j.iheduc.2010.03.0 02

27. Salikin, H., \& Tahir, S. Z. Bin. (2017). The social media-based approach in teaching writing at Jember University, Indonesia. International Journal of English
Linguistics, $\quad 7(3), \quad$ 1-12. https://doi.org/10.5539/ijel.v7n3p46

28. Santana, J. C., Santillán, A. G., \& Pozostexon, F. (2014). Learning vocabulary through Twitter. 7th International Conference of Education, Research and Innovation, November, 4178-4184. https://www.researchgate.net/publication/ 270890491_Learning_Vocabulary_throug h_Twitter/Accessed:2021-09-10

29. Siddique, M., \& Nair, M. S. (2015). The effectiveness of using mobile phones in enhancing writing skills: Teacher's and students' reflections. Australian Journal of Basic and Applied Sciences, 9(37), 390396.

http://repo.uum.edu.my/17941/Accessed:2 021-09-27

30. Sulisworo, D., Rahayu, T., \& Akhsan, R. N. (2016). The students' academic writing skills after implementing blended learning using Facebook. Information Technologies and Learning Tools, 56(6), 176.

https://doi.org/10.33407/itlt.v56i6.1477

31. Sysoyev, P. V., \& Pustovalova, O. V. (2014). Developing writing skills with "Twitter." Language and Culture, 3, 128136.

https://cyberleninka.ru/article/n/developin g-writing-skills-with-twitter/Accessed2021-09-17

32. Tatone, J., Derville Gallicano, T., \& Tefertiller, A. (2017). I love tweeting in class, but.... A qualitative study of student perceptions of the impact of Twitter in large lecture classes. Journal of Public Relations Education, 3(1), 1-13. https://aejmc.us/jpre/2017/05/24/i-lovetweeting-in-class-but-a-qualitative-studyof-student-perceptions-of-the-impact-oftwitter-in-large-lectureclasses/Accessed:2021-09-02

33. Tyma, A. (2011). Connecting with what is out there!: Using Twitter in the large lecture. Communication Teacher, 25(3), 175-181.

https://doi.org/10.1080/17404622.2011.57 9911

34. Veletsianos, G., Kimmons, R., \& French, K. D. (2013). Instructor experiences with a social networking site in a higher 
Risnawati et.al. The impact of using twitter as a pedagogical tool on improving writing skills of English language education students.

education setting: Expectations, frustrations, appropriation, and compartmentalization. Educational Technology Research and Development, 61(2), 255-278. https://doi.org/10.1007/s11423-012-9284$\mathrm{Z}$

35. Waters, R. D., \& Jamal, J. Y. (2011). Tweet, tweet, tweet: A content analysis of nonprofit organizations' Twitter updates. Public Relations Review, 37(3), 321-324. https://doi.org/10.1016/j.pubrev.2011.03.0 02

36. Welch, B. K., \& Bonnan-White, J. (2012). Twittering to increase student engagement in the university classroom. In An International Journal (Vol. 4, Issue 3). https://doi.org/https://citeseerx.ist.psu.edu/ viewdoc/download?doi=10.1.1.458.7902 \&rep=rep1\&type=pdf
37. West, B., Moore, H., \& Barry, B. (2015). Beyond the tweet: Using Twitter to enhance engagement, learning, and success among first-year students. Journal of Marketing Education, 37(3), 160-170. https://doi.org/10.1177/027347531558606 1

38. Yuan, H. C. (2012). Applying Twitter to EFL reading and writing in a Taiwanese college setting. Indiana State University. http://scholars.indstate.edu/handle/10484/ 4574/Accessed:2020-12-06

How to cite this article: Risnawati, Abdurrachman Faridi, Sri Wuli Fitriati. The impact of using twitter as a pedagogical tool on improving writing skills of english language education students. International Journal of Research and Review. 2022; 9(1): 129-141. DOI: https://doi.org/10.52403/ijrr. 20220118 